\title{
HUMOR W BADANIACH NAD PRZEKŁADEM
}

Problematyka przekładu humoru poruszana jest dość często we współczesnych badaniach przekładowych. Kwestię nieprzekładalności humoru realizującego się poprzez grę słów czy parodie przedstawił już w latach 50 . XX wieku Olgierd Wojtasiewicz ${ }^{1}$. Jak pokazuje praktyka przekładowa, humor był i jest często z powodzeniem - thumaczony. Istotne zatem wydaje się wypracowanie narzędzi umożliwiających ocenę trudności związanych z jego przekładem, opis strategii i technik tłumaczenia poszczególnych gatunków humorystycznych czy wreszcie stworzenie modeli znajdujących zastosowanie w praktyce przekładowej.

Dotychczasowe opracowania dotyczące przekładu humoru dotyczą najczęściej poszczególnych aspektów thumaczenia zjawisk humorystycznych, realizujących się w danych gatunkach tekstów. Oczywiście ze względu na to, że humor jest zjawiskiem niejednoznacznym interpretacyjnie, przyjmującym różne postaci, stworzenie uniwersalnych narzędzi jego opisu jest zadaniem trudnym, jeśli nie niemożliwym. Wydaje się jednak, że możliwe jest wypracowanie interdyscyplinarnego modelu analizy zjawisk humorystycznych wyrażanych za pomocą języka zarówno w krótkich formach narracyjnych, jak i złożonych, wielopoziomowych konstrukcjach, jak np. teksty audiowizualne.

Celem niniejszego artykułu jest przedstawienie ważniejszych kierunków refleksji językoznawczej i przekładoznawczej, a następnie wypracowanie instrumentarium do opisu humoru wyrażanego przez język w tekstach mono- i multisemiotycznych oraz ich przekładach. Refleksję poprzedza próba zdefiniowania analizowanego humoru, którego status ontologiczny nastręcza badaczom wielu trudności.

${ }^{1}$ O. Wojtasiewicz, Wstęp do teorii thumaczenia, Wydawnictwo Translegis, Warszawa 2007, s. 87,90 . 


\section{ZAKRES ZNACZENIOWY POJECCIA 'HUMOR'}

O trudności w wypracowaniu jednej definicji pojęcia 'humor' świadczą m.in. funkcjonujące w polszczyźnie kolokacje: szampański/wisielczy humor, mieć humory, tryskać humorem czy też humor z zeszytów szkolnych, które pozwalają postrzegać humor zarówno jako kategorię estetyczną, jak i psychologiczną zdolność człowieka. Trudnością w ustaleniu definicji jest też częściowa interferencja znaczeń słów humor i komizm. Słowniki języka polskiego podają, że 'humor' to „dyspozycja psychiczna polegająca na umiejętności zauważania zabawnych stron życia i traktowania ich z pobłażliwością i życzliwością”, „,nastrój przeżywany przez człowieka w danym momencie”, „forma komizmu, ujęcie w zabawny, żartobliwy sposób postaci, sytuacji, dialogów”"; ,zdolność dostrzegania komicznych stron życia”, „przedstawienie czegoś w zabawny sposób”, „,chwilowy nastrój”, wreszcie „umiejętność dostrzegania tego, co zabawne oraz rozśmieszania innych”, „cecha czegoś, co bawi, rozśmiesza”, „nastrój” oraz „dobry nastrój”4. Wielki słownik wyrazów obcych mianem humoru określa „,radosne nastawienie do życia”, „coś zabawnego, śmiesznego”, „chwilowy nastrój”; ‘humory’ zaś to inaczej „kaprysy, fumy, dąsy”. 'Komizm' natomiast to „cechy kogoś lub czegoś wywołujące śmiech, wesołość; przedstawianie w sposób śmieszny, np. w dziele sztuki; śmieszność”, , a także „efekt komiczny uzyskany w utworze artystycznym, cecha sytuacji, rzeczy, osoby budząca wesołość” czy wreszcie „efekt uzyskiwany w utworze artystycznym poprzez przedstawienie postaci, wypowiedzi, obyczajów lub sytuacji w sposób budzący rozbawienie odbiorcy"8.

Jak podaje Słownik terminów literackich, termin komizm określa właściwość charakterystyczną dla pewnych konfiguracji zjawisk spotykanych w życiu lub przedstawianych przez sztukę, powodującą reakcję w postaci śmiechu lub wesołości i wykluczającą silne emocje negatywne ${ }^{9}$. Komizm zaliczany jest tu do kategorii estetycznych, a jedną z jego postaci jest humor, określany jako dyspozycja do ujmowania zjawisk w kategoriach komizmu, żartobliwy sposób przedstawiania

${ }^{2}$ B. Dunaj (red.), Stownik wspótczesnego języka polskiego, Wydawnictwo Wilga, Warszawa 1996, s. 311.

${ }^{3}$ L. Drabik et al., Stownik języka polskiego PWN, Wydawnictwo Naukowe PWN, Warszawa 2010, s. 265.

${ }^{4}$ P. Żmigrodzki (red.), Wielki stownik języka polskiego PAN, Instytut Języka Polskiego PAN, Kraków, <http://www.wsjp.pl> [dostęp: 20.03.2016].

5 A. Latusek, Wielki stownik wyrazów obcych, Krakowskie Wydawnictwo Naukowe, Kraków 2009, s. 363.

${ }^{6}$ B.B. Dunaj (red.), op. cit., s. 397; A. Latusek, op. cit., s. 456.

${ }^{7}$ L. Drabik et al., op. cit., s. 340.

${ }^{8}$ P. Żmigrodzki (red.), op. cit.

9 J. Sławiński et al., Słownik terminów literackich, Zakład Narodowy im. Ossolińskich, Wrocław-Warszawa-Kraków 2002, s. 251-252. 
postaci lub sytuacji, będący przejawem życzliwej, wolnej od drwiny, szyderstwa i nienawiści postawy do świata ${ }^{10}$.

Biorąc pod uwagę brak całkowitej jednoznaczności terminologicznej oraz coraz powszechniejsze użycie terminu komizm w stosunku do zmysłu humorystycznego przejawiającego się także poza literaturą ${ }^{11}$, można uznać, że zarówno humor, jak i komizm określają sposób ujmowania rzeczywistości, mogący powodować rozbawienie lub śmiech. Zakres znaczeniowy określenia humor zdaje się jednak bliższy rozpowszechnionym na gruncie międzynarodowym internacjonalizmom - zapewni więc przejrzystość i jednolitość terminologiczną, a zarazem umożliwi sprawniejszy przekład przytaczanych w dalszym ciągu obcojęzycznych opracowań.

\section{HUMOR W BADANIACH JĘZYKOZNAWCZYCH}

Ważne miejsce w badaniach nad humorem w przekładzie międzyjęzykowym zajmuje analiza językoznawcza humoru wyrażanego przez język. W większości teorii językoznawczych przedmiotem badań są krótkie formy humorystyczne zakończone puentą, jak np. dowcip ${ }^{12}$, część wypracowanych przez nie narzędzi może jednak okazać się użyteczna w badaniach innych odmian humoru.

W duchu semantyki strukturalnej badano m.in. organizację struktury tekstu humorystycznego. Twórca modelu izotopii dyskursywnych, Algirdas Julien Greimas, jest autorem teorii, zgodnie z którą na humorystyczną anegdotę składają się dwie płaszczyzny będące w opozycji wobec siebie, a opozycja ta ukryta jest za pomocą terminu łączącego ${ }^{13}$. Uwagę strukturalistów przyciągały też funkcje sekwencji zabawnych tekstów ${ }^{14}$, natura elementów umożliwiających przejście z jednej izotopii do drugiej i zakamuflowanie tego przejścia ${ }^{15}$ czy też charakter elementu rozprzęgającego ${ }^{16}$.

Metody strukturalne zwracają uwagę na charakter bodźca humorystycznego, spowodowanego przez niespójność między dwiema sprzecznymi płaszczyznami komunikatu, ale mogą być kwestionowane w przypadku humoru wymagającego

${ }^{10}$ Ibidem, s. 203, s. 251-252.

${ }^{11}$ Zob. np. strona Stowarzyszenia Badań nad Humorem (International Society for Humor Studies).

12 Por. S. Attardo, Linguistic Theories of Humor, Mouton de Gruyter, Berlin-New York 1994, s. 230.

13 A.J. Greimas, Sémantique structurale, Larousse, Paris 1966, s. 70-71.

14 V. Morin, „L'histoire drôle”, Communications 8, 1966, s. 102-119.

15 P. Charadeau, „Quelques procédés linguistiques de l'humour”, Revue des langues modernes 3, 1972, s. 62-73.

${ }^{16}$ S. Attardo et al., „The linear organization of jokes: statistical analysis of two thousand texts", Humor: International Journal of Humor Research 7(1), 1994, s. $27-54$. 
odniesienia do kontekstu pozajęzykowego, wyrażanego pomimo braku elementów rozprzęgających w strukturze powierzchniowej komunikatu.

$\mathrm{W}$ optyce semantycznej z kolei rozwinęła się m.in. semantyczna teoria skryptów (Script-based Semantic Theory of Humor) Victora Raskina, który przedmiotem badań uczynił dowcipy (jokes) lub dłuższe teksty zawierające dowcipy (joke-carrying texts), a za podstawowe pojęcie uznał pojęcie skryptu, tj. nośnika informacji semantycznej oraz pewnej wiedzy o świecie. Według Raskina za humorystyczny może zostać uznany tekst, który pokrywa się częściowo lub w całości z dwoma różnymi skryptami będącymi w opozycji względem siebie. Teoria została rozwinięta przez Raskina i Salvatore Attardo jako ogólna teoria humoru werbalnego (General Theory of Verbal Humour), z założenia mająca znaleźć zastosowanie w badaniu wszelkiego rodzaju tekstów humorystycznych. W przeciwieństwie do semantycznej teorii skryptów ogólna teoria wykorzystuje narzędzia wypracowane przez różne dziedziny językoznawstwa, jak np. lingwistyka tekstu czy pragmatyka. Analizując różnice między dowcipami z tej samej serii (joke series), związane z typem narracji, sytuacją, osobą bohatera, logiką puenty czy typem opozycji, Raskin i Attardo wskazali pięć, oprócz opozycji skryptów, elementów będących częściami składowymi dowcipów. Są to: warstwa językowa, strategia narracyjna, przedmiot/cel dowcipu, sytuacja i mechanizm logiczny ${ }^{17}$.

Pojęcie skryptu może być także podstawą do analizy humoru z perspektywy socjo- i etnolingwistycznej. Na przykład humor wynikający z zestawienia różnych odmian językowych jest w tym ujęciu definiowany jako aktywacja dwóch lub więcej skryptów aktywujących inne skrypty, wśród których co najmniej dwa pozostają $\mathrm{w}$ relacji antonimii ${ }^{18}$. Teoria umożliwia badanie leksykalnych aspektów rejestru, abstrahuje natomiast od jego cech składniowych czy fonetycznych. Niemniej jednak, uzupełniona o opis pozostałych cech systemowych, może być zastosowana $\mathrm{w}$ analizie humorystycznych niespójności wynikających z zestawienia różnych odmian języka i może dać podstawy do wyjaśnienia potencjalnych różnic w odbiorze przekładu efektów humorystycznych.

Badanie humoru $\mathrm{w}$ perspektywie etnolingwistycznej ukazuje natomiast związki humorystycznej opozycji skryptów z rzeczywistymi stereotypami zakorzenionymi w świadomości danej społeczności ${ }^{19}$, dając podstawy do oceny efektów humorystycznych oryginału i przekładu oraz do znalezienia przyczyn ewentualnej nieprzekładalności tego typu humoru. Ponadto teza dotycząca skryptu wymienności, na którym bazuje każdy dowcip etniczny, uzasadnia poszukiwanie

17 Jak wykazał Attardo, porównanie tych parametrów w tekście wyjściowym i jego przekładzie może być wykorzystane w badaniach przekładowych (zob. punkt 3.4.)

18 S. Attardo, Linguistic Theories..., s. 246-253.

19 D. Brzozowska, Polski dowcip etniczny: stereotyp a tożsamość, Wydawnictwo Uniwersytetu Opolskiego, Opole 2008. 
uniwersalnych cech humoru etnicznego. Założenie, że takie cechy istnieją, także może być istotne dla porównania efektów oryginału i przekładu, uzyskanych poprzez odniesienie do stereotypów związanych z daną społecznością.

Przedmiotem badań czerpiących z założeń pragmatyki jest m.in. humor rozumiany jako naruszenie ogólnie przyjętych reguł konwersacji. Jedno ze stawianych pytań dotyczy efektów humorystycznych uzyskiwanych poprzez naruszenie maksym konwersacyjnych Grice'a ${ }^{20}$. Inne kwestie wiążą się z założeniami teorii relewancji Dana Sperbera i Deirdre Wilson. $Z$ jednej strony, ponieważ różne są doświadczenia, środowiska poznawcze oraz zdolności komunikacyjne nadawcy i odbiorcy, intencje komunikacyjne mówiącego nie zawsze zostają odczytane poprawnie w rzeczywistej interakcji, co może prowadzić do nieporozumień, a w konsekwencji do efektów humorystycznych ${ }^{21}$. Z drugiej strony procesy zachodzące w mechanizmie inferencyjnym mogą być przedmiotem świadomej manipulacji w tekstach humorystycznych. Humor dowcipów może wynikać z zakwestionowania interpretacji eksplikatury, ze zderzenia interpretacji eksplicytnej z założeniami kontekstowymi, gry z przesłankami i konkluzjami oraz stereotypami w umyśle odbiorcy ${ }^{22}$.

Obie metody dostarczają ważnych narzędzi analizy humoru, mogą bowiem zostać wykorzystane $\mathrm{w}$ opisie zjawisk $\mathrm{z}$ różnych poziomów semiologicznych, składających się na sytuację komunikacyjną. Ponadto opis hipotetycznych interferencji, które mogą zajść w umyśle hipotetycznego odbiorcy, sytuuje efekt humorystyczny na poziomie relacji między postrzegającym a przedmiotem i może być niezbędnym narzędziem wyjaśnienia humoru wpisującego się w określony kontekst komunikacji kulturowej, tj. między autorami utworu i jego potencjalnymi odbiorcami.

$\mathrm{Na}$ gruncie analizy dyskursu powstał semantyczno-pragmatyczny model opisu humoru. Na podstawie pojęcia schematu poznawczego Jeroen Vandaele na nowo zdefiniował klasyczne pojęcia niespójności (incongruity) i poczucia wyższości (superiority). Niespójność, rozumiana tradycyjnie jako kontrast między tym, czego się oczekuje, a tym, co rzeczywiście następuje, została tu zdefiniowana jako zaprzeczenie schematu poznawczego, poczucie wyższości z kolei jako zespół elementów społecznych uczestniczących w dynamice humoru. Zdaniem autora oba mechanizmy współdziałają w interakcji humorystycznej, dlatego opis zjawisk humorystycznych powinien uwzględniać różne typy niespójności i poczucia wyższości współdziałające ze sobą: niespójności językowe, pragmatyczne,

${ }^{20}$ Y. Wu, Y. Chen, „Humor Strategies in the American Sitcom 'Friends': An Empirical Study with Reference to Grice's Cooperative Principle", <http://140.127.82.166/bitstream/987654321/2023/1/5.pdf [dostęp: 28.03.2014].

${ }^{21}$ Por. S. Hu, „An Analysis of Humor in The Big Bang Theory from Pragmatic Perspectives”, Theory and Practice in Language Studies 2(6), 2012, s. 1185-1190.

22 F. Yus, „A Relevance-Theoretic Classification of Jokes”, Lodz Papers in Pragmatics 4(1), 2008, s. 131-157. 
narracyjne, usytuowane w dziedzinie sztuki (parodia), w obszarze społecznym (satyra), i niespójności ogólne, a także dwa rodzaje poczucia wyższości: agresywne oraz afirmatywne, niezorientowane na $\operatorname{cel}^{23}$. Powiązanie obu mechanizmów umożliwia analizę znaków na poziomie tekstu oraz proces ich odbioru. Ponadto metoda, wpisująca się w nurt analizy dyskursu, dostarcza narzędzi analizy wielosemiotycznej struktury, jaką jest tekst audiowizualny.

Metody językoznawcze mogą z całą pewnością znaleźć zastosowanie w badaniach nad przekładem, dostarczając narzędzi opisu technik służących uzyskaniu efektu humorystycznego. Różnorodność stosowanych technik pociąga jednak za sobą cały wachlarz trudności przekładowych. Określeniu charakteru trudności związanych z przekładem humoru może służyć typologia środków humorystycznych oryginału.

\section{HUMOR W BADANIACH NAD PRZEKŁADEM}

\section{1. ŚRODKI SŁUŻĄCE UZYSKANIU EFEKTU HUMORYSTYCZNEGO}

Rozróżnienie między humorem językowym, opartym na fonicznej lub graficznej reprezentacji elementu humorystycznego, oraz referencyjnym, opartym na znaczeniu, sięga czasów antycznych. W terminologii Cycerona dowcipy (łac. $f a-$ cetiae) mogą dotyczyć rzeczy (re) lub tego, co jest powiedziane (dicto): „Co tedy jakimkolwiek słowy powiedziane jest śmiesznem, w słowach ma swą całą przyjemność (...). A że takie żarty straciłyby swój wdzięk, gdyby odmieniono wyrazy przytoczonego przysłowia, trzeba je umieścić w rzędzie żartów na słowach, nie na rzeczy opartych"24.

Podział określony przez Cycerona stał się punktem odniesienia dla współczesnych autorów typologii humoru i tekstów humorystycznych. Violette Morin wyróżniła np. opowiadania, w których humor ma charakter semantyczny (fr. récit à disjonction sémantique) i w których dysjunktorem łączącym izotopie jest znak, oraz te $\mathrm{z}$ humorem referencyjnym (récit à disjonction référentielle), kiedy dysjunktor jest elementem, do którego odsyłają znaki ${ }^{25}$. Dla Charlesa Hocketta z kolei klasyczne rozróżnienie stało się podstawą do przeciwstawienia sobie dwóch typów tekstów humorystycznych: dowcipów pisanych prozą (ang. prosaic jokes), dotyczących pewnej wiedzy o świecie, oraz dowcipów poetyckich (poetic jokes),

23 J. Vandaele, „Humor Mechanisms in Film Comedy: Incongruity and Superiority”, Poetics Today 23(2), 2002, s. 221-249.

${ }^{24}$ Cyceron, Pisma krasomówcze i polityczne Marka Tyliusza Cycerona, przeł. E. Rykaczewski, nakładem Biblioteki Kórnickiej, Poznań 1873, s. 149, 152.

${ }^{25}$ V. Morin, op. cit., s. 103. 
których nośnikiem jest język ${ }^{26}$. Inni jeszcze przekładoznawcy wyróżnili trzy kategorie dowcipów: dowcipy uniwersalne, językowe oraz kulturowe ${ }^{27}$.

Wyróżnione odmiany humoru, zarówno te o charakterze językowym, jak i referencyjnym, realizują się za pomocą języka. W przypadku humoru multisemiotycznego istotne jest natomiast oddzielenie humoru werbalnego (verbal) - językowego (linguistic), opartego na zmianach w obrębie systemu języka, i niejęzykowego (non-linguistic) — od niewerbalnego, przekazywanego za pomocą innych kanałów, np. dźwiękowego lub wizualnego ${ }^{28}$. Bardziej szczegółową charakterystykę humorystycznych elementów realizujących się w tekstach multisemiotycznych proponuje Patrick Zabalbeascoa, autor typologii dowcipów filmowych, stworzonej na podstawie kryterium natury trudności, które może sprawiać ich przekład ${ }^{29}$. W klasyfikacji uwzględnione zostały:

- Dowcipy międzynarodowe (international jokes), których efekt humorystyczny nie zależy od gry słów w danym języku ani od znajomości określonych aspektów kultury wyjściowej. Ponieważ jednak to, co uważane jest za dowcip międzynarodowy w jednej kulturze, $\mathrm{w}$ innej może stanowić problem przekładowy, Zabalbeascoa proponuje odnosić się do konkretnych par języków oraz kultur i używać terminu dwunarodowe (binational).

- Dowcipy odnoszące się do kultury narodowej i instytucji (nationalculture-and-institutions jokes).

- Dowcipy wynikające z narodowego poczucia humoru (national-sense-of-humour jokes). Określenie to odnosi się do pewnych typów dowcipów oraz ich tematów, bardziej popularnych w jednych krajach i społecznościach niż w innych. Lokalne preferencje zależą od kultury, religii oraz historycznych lub politycznych powiązań z sąsiednimi nacjami.

- Dowcipy związane ze szczególnym użyciem języka (language-depending jokes), zależne od właściwości danego języka zastosowanych do uzyskania

${ }^{26}$ Za: D. Chiaro, The Language of Jokes. Analysing Verbal Play, Routledge, London 1992, s. 4.

27 S.D. Raphaelson-West, „On the Feasibility and Strategies of Translating Humor”, Meta : Journal des traducteurs 34(1), 1989, s. 128-141; A.-M. Laurian, „Possible/impossible translation of jokes", Humor: International Journal of Humor Research 5 (1-2), 1992, s. 111-127.

${ }^{28}$ Zob. R.J. Alexander, Aspects of Verbal Humour in English, Gunter Narr Verlag, Tübingen 1997.

${ }^{29}$ Klasyfikacja Zabalbeascoa dotyczy elementów humorystycznych, które mogą sprawić trudności w przekładzie realizującym się w formie dubbingu. Oczywiste jest, że wybór formy przekładu audiowizualnego w znacznej mierze wpływa na wybór strategii i technik thumaczenia humoru. Przedstawiony przez nas artykuł jest częścią rozprawy doktorskiej Humor w przekładzie audiowizualnym. Na przykładzie filmów 'Les Visiteurs' $i$ 'Bienvenue chez les Ch 'tis' $i$ ich polskich wersji [publikacja w przygotowaniu, ukaże się nakładem wydawnictwa Universitas], w której bardziej szczegółowo opisana jest typologia form przekładu audiowizualnego oraz trudności przekładowe wynikające z wyboru danej formy TAW (tłumaczenia audiowizualnego). 
efektu, takiego jak polifonia, homofonia czy zeugma. Ich mniej lub bardziej dosłowne tłumaczenie jest możliwe, gdy dwa języki są ściśle powiązane ze sobą.

- Dowcipy wizualne (visual jokes), odsyłające zarówno do humoru obserwowalnego na ekranie, jak i będącego jedynie wizualną formą dowcipów językowych, np. w postaci rebusów.

- Dowcipy zlożone (complex jokes), łączące co najmniej dwa typy dowcipów ${ }^{30}$.

Jak widać, klasyfikacja uwzględnia przede wszystkim środki uzyskane na poziomie werbalnym, które teoretycznie stanowią jedyne źródło trudności operacji przekładowych dokonujących się na poziomie tekstu. Dla potrzeb badania humoru audiowizualnego konieczne jest jednak rozszerzenie klasyfikacji o środki przekazywane także na innych poziomach semiotycznych. Mimo że nie stanowią one rzeczywistej materii przekładu, to jednak właśnie one wpływają (a przynajmniej powinny) na decyzje thumaczeniowe.

Częściowej modyfikacji klasyfikacji Zabalbeascoa dokonał Juan-José Martinez-Sierra, który przedmiotem analizy uczynił nie tylko dowcipy, lecz także wszelkie zjawiska powodujące efekt humorystyczny w tekstach audiowizualnych. Oprócz elementów odnoszących się do społeczności i instytucji (community-andinstitutions elements), tj. wszelkich kulturowych i intertekstualnych odniesień humorystycznych, powiązanych $\mathrm{z}$ daną kulturą i realizujących się implicytnie lub wprost zarówno na poziomie werbalnym, jak i wizualnym, elementów związanych ze wspólnotowym poczuciem humoru (community-sense-of-humour elements), elementów językowych (linguistic elements), Martinez-Sierra wyróżnił: elementy wizualne (visual elements), odnoszące się zarówno do humorystycznych środków stricte wizualnych, jak i tych będących wizualnym powieleniem komunikatu werbalnego, elementy graficzne (graphic elements), w których efekt humorystyczny realizuje się poprzez wiadomości tekstowe widoczne na ekranie (np. napisy na bannerach); elementy parajęzykowe (paralinguistic elements), które dostarczają pewnych dodatkowych informacji i obejmują niewerbalne cechy głosu, takie jak wysokość, natężenie, intonacja czy cisza narracyjna, powiązane z wyrażającymi uczucia krzykiem, westchnieniami, śmiechem; elementy dźwiękowe (sound elements), tj. dźwięki należące do fabuły lub efekty specjalne, które same w sobie lub w połączeniu z innymi elementami tworzą efekt humorystyczny, oraz nieokreślone elementy (humorystyczne) [non-marked (humourous) elements], które nie przynależą do żadnej grupy, a jednak są humorystyczne.

Martinez-Sierra upatruje źródeł efektów humorystycznych w relacji odbiorcy do postrzeganego bodźca. Istotnym czynnikiem w procesie tworzenia znaczeń humorystycznych jest zdaniem autora teoria relewancji, która pozwala powiązać efekt humorystyczny $\mathrm{z}$ istniejącymi $\mathrm{w}$ umyśle odbiorcy założeniami oraz

30 P. Zabalbeascoa, „Translating Jokes for Dubbed Television Situation Comedies”, The Translator 2(2), 1996, s. 251-254. 
założeniami kontekstowymi na poziomie fabuły. Efekt poznawczy w postaci implikacji wysnutych na podstawie sprzeczności między tymi założeniami prowadzi do efektu humorystycznego ${ }^{31}$. Postrzeganie tego efektu w kategoriach poznawczych zakłada obecność odbiorcy jako niezbędnego aktanta biorącego udział w tworzeniu znaczeń humorystycznych. Przyjęta przez Martineza-Sierrę typologia pozwala jednocześnie na powiązanie elementów humorystycznych z różnych poziomów semiologicznych z pozatekstowym kontekstem ich odbioru, tj. sposobem funkcjonowania w kulturze oryginału. Tylko taka perspektywa może dać podstawy do porównania ewentualnych różnic w funkcjonowaniu tekstów w kulturze wyjściowej i docelowej. Porównanie efektów humorystycznych oryginału i przekładu prowadzi do konieczności zdefiniowania przekładu tekstu humorystycznego.

\subsection{DEFINICJA PRZEKŁADU TEKSTU HUMORYSTYCZNEGO}

Interlingwalny przekład tekstu humorystycznego różni się od przekładu innych rodzajów tekstów. Po pierwsze, tekst humorystyczny może powodować dostrzegalny efekt w postaci uśmiechu lub śmiechu. Ponieważ produkcja i percepcja humoru są niezależne od siebie, tłumacz, będący jednocześnie odbiorcą i nadawcą, (współ)autorem tekstu przekładu, może doświadczać humoru oryginału i jednocześnie być niezdolnym do jego reprodukcji. Vandaele zauważa, że ponieważ odbiór humoru ma charakter indywidualny, odtwarzanie go zależy również od poczucia humoru thumacza, który może zostać postawiony przed dylematem, czy tłumaczyć dowcip, który sam uważa za mało śmieszny, czy raczej dążyć do osiągnięcia „prawdziwie” humorystycznego efektu. $Z$ drugiej strony, humor ten może wywrzeć na tłumaczu tak wielki efekt, że nie będzie on w stanie przeprowadzić racjonalnej analizy oryginału i dokonać przekładu. Argumenty te pokazują, że tłumaczenie humoru zależy m.in. od predyspozycji tłumacza, nie ma więc jednej recepty na prawidłowe thumaczenie humoru ${ }^{32}$.

Tłumaczenie humoru łączone jest często z problemem nieprzekładalności przede wszystkim ze względu na samą specyfikę tekstu humorystycznego: „chociaż tłumaczenia tekstów humorystycznych istnieją już od początków tłumaczenia w ogóle, sceptycyzm wobec przekładalności humoru jest wciąż powszechny w przekłado- i literaturoznawstwie"33.

${ }^{31}$ J.J. Martinez-Sierra, „Translating Humor. A Case Study”, Perspectives: Studies in Translatology 13(4), 2006, s. 290-292.

32 J. Vandaele, „Introduction. (Re-)Constructing Humour: Meanings and Means”, The Translator 8(2), 2002, s. 149-172.

33 „Although translations of humorous texts have existed ever since translation began (...) scepticism about the translatability of humour is still widespread in Translation and Literature Studies” (E.E. Borrás, „Humour in translation. Joe Orton's The Ruffian on the Stair and its Catalan and Valencian Versions", [w:] P. Jansen (ed.), Translation and the Manipulation of Discourse. 
Dla wythumaczenia faktu, że humor jest jednak (często skutecznie) tłumaczony ${ }^{34}$, o czym świadczy popularność serii dowcipów czy komedii filmowych na rynku międzynarodowym, można by odnieść się do słów Romana Jakobsona, bliskiego uniwersalistycznemu podejściu do thumaczenia: „całe doświadczenie poznawcze i jego klasyfikację da się przekazać w każdym istniejącym języku (...), a brak jakiegokolwiek elementu gramatycznego w języku, na który się przekłada, nie stanowi żadnej przeszkody w dosłownym przetłumaczeniu całej informacji pojęciowej zawartej w oryginale" 35 .

Jednak w przypadku humoru, na którego wartość składa się często konkretna forma poszczególnych elementów składowych, najczęściej niedających się zastąpić wyrażeniami synonimicznymi, trudno nie zgodzić się z Umberto Eco, iż

ekwiwalencja znaczeniowa nie może być traktowana jako satysfakcjonujące kryterium prawidłowego przekładu (...). Nie możemy nawet zgodzić się z naiwnym poglądem, że ekwiwalencję znaczeniową zapewnia użycie synonimu. Powszechnie przyjęte jest bowiem, że w języku nie istnieją synonimy całkowite. Father nie jest synonimem daddy, daddy nie jest synonimem papa, a père nie jest synonimem padre ${ }^{36}$.

Można przyjąć, że w przypadku humoru przekład nie może być postrzegany jako wierne odwzorowanie oryginału, ale musi być definiowany w kategoriach ekwiwalencji dynamicznej, polegającej na oddaniu w przekładzie funkcji, jaką oryginał pełni w języku wyjściowym i spowodowaniu tego samego efektu

Selected Papers of the CERA Research Seminars in Translation Studies, Leuven 1994, s. 39) przeł. A. R. Tezę o nieprzekładalności humoru zdaje się potwierdzać m.in. to, że humor nie daje się zdefiniować wyłącznie w kategoriach językoznawczych — jako znaczenie semantyczne przyporządkowane formie językowej lub, innymi słowy, jako literalne znaczenie przekazu. Jak zauważa Danuta Buttler, „komiczność nie jest stałą, immanentną cechą przedmiotów, ale realizuje się w pewnym doraźnym układzie sytuacyjnym i bywa wypadkową działania różnorodnych czynników" (D. Buttler, Polski dowcip językowy, Wydawnictwo Naukowe PWN, Warszawa 2001, s. 8).

34 Jak stwierdzają Jorge Díaz-Cintas i Aline Remael, ,w literaturze dotyczącej przekładu humoru wiele uwagi poświęca się kwestiom jego (nie)przekładalności albo przynajmniej trudnościom tłumaczeniowym. A przecież humor, czy to książkowy, sceniczny czy filmowy łatwo daje się transportować. Innymi słowy: humor z pewnością jest w jakiś sposób thumaczony” („In the literature on the translation of humour much attention is devoted to questions relating to its (un)translatability, or at least to the difficulties involved in its translation. However, in practice, comedies have proved to travel well, be it in book form, on the stage, or on the screen. In other words: humour is certainly translated somehow" - J. Díaz-Cintàs, A. Remael, Audiovisual translation: Subtitling, St. Jerome Publishing, Manchester 2007, s. 212) - przeł. A. R.

35 R. Jakobson, „O językoznawczych aspektach przekładu”, [w:] idem, W poszukiwaniu istoty języka, t. 1, wybór, redakcja naukowa i wstęp M.R. Mayenowa, Państwowy Instytut Wydawniczy, Warszawa 1989, s. 372-381.

36 „Equivalence in meaning cannot be taken as a satisfactory criterion for a correct translation (...). We cannot even accept the naïve idea that equivalence in meaning is provided by synonym, since it is commonly accepted that there are no complete synonym in language. Father is not a synonym for $d a d d y, d a d d y$ is not a synonym for papa, and père is not a synonym for padre" (U. Eco, Experiences in Translation, przeł. A. McEwan, University of Toronto Press, Toronto 2001, s. 9) przeł. A. R. 
u jego odbiorcy ${ }^{37}$. Z tego powodu thumaczenie humoru będziemy za Vandaele'em postrzegać w kategoriach funkcjonalnych jako relację między dwoma tekstami powodującymi taki sam lub zbliżony efekt, a za taki efekt uznawać będziemy efekt humorystyczny ${ }^{38}$. Nie ulega wątpliwości, że możliwość uzyskania w przekładzie zbliżonego efektu związana jest $\mathrm{w}$ dużej mierze $\mathrm{z}$ naturą elementu humorystycznego oryginału. Warto więc zasygnalizować zaobserwowane dotychczas przez teoretyków i praktyków przekładu trudności w tłumaczeniu tekstów humorystycznych.

\subsection{PRZEKŁADALNOŚĆ TEKSTÓW HUMORYSTYCZNYCH}

Dotychczasowe badania przypisują poszczególnym odmianom tekstów humorystycznych różne stopnie trudności ich tłumaczenia. Według Anne-Marie Laurian szczególnych trudności w thumaczeniu nie sprawiają dowcipy ogólne (ang. general jokes), ponieważ sytuacja w nich przedstawiona wydaje się niezwiązana z daną nacją, państwem czy kulturą ${ }^{39}$. Zdaniem Debry Raphaelson-West ich tłumaczenie może stanowić jednak pewną trudność, jako że nie wszystkie kultury postrzegają jako śmieszne te same sytuacje ${ }^{40}$. Obie badaczki są jednak zgodne co do tego, że największy problem przekładowy stanowi humor językowy. Trudnością może być bowiem nie tylko rodzaj dowcipu (oparty na niejednoznaczności fonetycznej, leksykalnej bądź morfoskładniowej), ale też relacje między językiem wyjściowym i docelowym ${ }^{41}$. Mniej problematyczny jest teoretycznie przekład dowcipów kulturowych, chociaż, jak zauważa Laurian: „,czasem nie ma tzw. problemu thumaczeniowego: język jest łatwy, prosty, zrozumiały dla wszystkich. A jednak «duch» tego języka zdaje się trudny do wyrażenia w innym języku, lub raczej, nawet jeśli jest wyrażony, nie powoduje śmiechu"42.

37 „Przekład natomiast, który zmierza do ekwiwalencji dynamicznej, a nie formalnej, opiera się na zasadzie ekwiwalentnego efektu (...). Tłumacz stara się nie tyle o dostosowanie komunikatu w języku przekładu do komunikatu w języku źródłowym, ile o relację dynamiczną: o to, aby relacja między komunikatem i odbiorcą przekładu była zasadniczo ta sama co relacja pomiędzy tym komunikatem i odbiorcą oryginału” (E. Nida, „Zasady odpowiedniości”, przeł. A. Skucińska, [w:] P. Bukowski, M. Heydel (red.), Wspótczesne teorie przekladu. Antologia, Wydawnictwo Znak, Kraków 2009, s. 53-69).

38 J. Vandaele, „Introduction. (Re-)Constructing Humour...”, s. 151-152.

39 A.-M. Laurian, op. cit., s. 114.

40 S.D. Raphaelson-West, op. cit., s. 131.

${ }^{41}$ Wyniki ankiety przeprowadzonej wśród 120 agencji thumaczeniowych w Rzymie i Mediolanie, tworzących włoski rynek dubbingowy, pokazały, że tłumaczenie humoru wyrażonego za pomocą języka (Verbally Expressed Humor) jest jednym z największych wyzwań podczas tworzenia thumaczeń filmowych (za: D. Chiaro, „Verbally Expressed Humour on Screen: Reflections on Translation and Reception”, JoSTrans 6, 2006, <http://www.jostrans.org/issue06/art_chiaro.php> [dostęp: 19.10.2015]).

42 "Sometimes there is not so-called translation problem: the language is easy, simple, understandable by all. Yet the 'spirit' of it seems hard to express in another language, or, better said, even 
Choć z punktu widzenia semantycznego wersja oryginalna i przekład będą zbliżone do siebie, czynniki pragmatyczne i kulturowe mogą sprawić, że oryginał będzie stwarzał poważne trudności w przekładzie. Wyjątkiem mogą być np. dowcipy etniczne, często oparte na podobnym schemacie, tj. wyśmiewające głupotę innej nacji. W tym przypadku zmiana obiektu dowcipu nie musi wpływać na jego śmieszność ${ }^{43}$. Z kulturowego punktu widzenia trudność może też sprawiać przekład satyry i parodii, których przedmiotem jest często obiekt znany tylko w kulturze wyjściowej ${ }^{44}$.

Inną klasyfikację elementów humorystycznych stanowiących problem w przekładzie zaproponował Vandaele, wyróżniając trzy obszary mogące być źródłem trudności w thumaczeniu humoru wyrażanego za pomocą języka. Pierwszy z nich przejawia się w związku między językiem a kulturą, którą język odzwierciedla. Trudności w przekładzie mogą pojawiać się zarówno na poziomie denotatywnym (elementy kulturowe nieistniejące w kulturze odbioru), jak i konotatywnym (konotacje rozumiane tylko przez członków danej kultury). Drugi stanowią warianty społeczne języka (dialekty, socjolekty, rejestry), trzeci natomiast realizuje się na planie metajęzykowym, kiedy znaki zostają wypowiedziane nie tylko ze względu na treść, ale przede wszystkim ze względu na formę ${ }^{45}$.

Biorąc pod uwagę to, że nie wszystkie elementy humorystyczne charakteryzują się jednakowym stopniem przekładalności, nasuwa się pytanie o sposób ich tłumaczenia. Mając świadomość, że idealny przepis na tłumaczenie humoru jest niemożliwy, niektórzy badacze podejmowali się jednak opracowania możliwych modeli przekładu elementów humorystycznych.

\subsection{MODELE TŁUMACZENIA HUMORU}

Według Zabalbeascoa thumaczenie dowcipów powinno przebiegać w dwóch etapach. Pierwszy z nich polega na wyodrębnieniu ich i określeniu kategorii, do której przynależą. Zabalbeascoa do pierwszej kategorii zaliczył łatwo przekładalne dowcipy, nieograniczone barierami językowymi ani kulturowymi. Ponieważ w tym przypadku języki i kultury wyjściowe i docelowe nakładają się na siebie, nie ma potrzeby adaptacji czy substytucji elementów humorystycznych. Inny

if it is expressed, it would be not laughed at" (A.-M. Laurian, op. cit., s. 122) - przeł. A. R.

${ }^{43}$ Christie Davies w swojej pracy poświęconej dowcipom etnicznym przedstawia listę wybranych grup etnicznych, którym przypisywana jest głupota lub spryt: w Stanach Zjednoczonych przedmiotem takich dowcipów są Polacy, w Anglii - Irlandczycy, a w Rosji - Ukraińcy (zob.

C. Davies, Ethnic Humor Around the World. A Comparative Analysis, Indiana University Press, Bloomington-Indianapolis 1996, s. 11-12).

44 S.-D. Raphaelson-West, op. cit., s. 132-135.

45 J. Vandaele, „Si sérieux s'abstenir. Le discours sur l'humour traduit”, Target 13:1, 2001, s. $35-37$. 
charakter mają natomiast dowcipy ograniczone atrybutami osobowościowymi odbiorcy, np. wiedzą językową i kulturową, stopniem znajomości lub upodobania pewnych tematów, gatunków i typów humoru. Problem przekładu tych dowcipów nie wynika $\mathrm{z}$ ograniczeń języka, lecz z dystansu poznawczego między wiedzą potrzebną do ich odkodowania a tą, którą posiada odbiorca ${ }^{46}$. Trudności może też sprawiać humor przynależny danej grupie społecznej (mieszkańcom miasta, uczniom danej szkoły itp.), często posługującej się jednym socjolektem lub dialektem (w niektórych przypadkach kategoria ta pokrywa się z grupą dowcipów ograniczonych atrybutami odbiorcy).

Kolejnym aspektem, który należy wziąć pod uwagę w procesie thumaczenia dowcipów, jest ich intencjonalność. Przed podjęciem decyzji o przekładzie danego elementu tłumacz powinien ocenić, czy jest on świadomym działaniem nadawcy oryginału, czy raczej efektem ubocznym jego pracy. Jednocześnie sam powinien unikać niezamierzonych efektów humorystycznych wpływających na treść przekładu. Ważne jest również, czy humor oryginału był wcześniej przemyślany, czy też został przekazany spontanicznie. W obu przypadkach może się to wiązać z trudnościami w przekładzie - w pierwszym ze względu na ewentualne szczegółowe opisy i niuanse, w drugim zaś może być utrudnieniem dla tłumaczy ustnych. Ponadto należy też zwrócić uwagę, czy dowcipowi towarzyszą sygnały świadczące o zamiarze przekazania go przez nadawcę. Brak wyraźnych sygnałów może skutkować nieprzetłumaczeniem dowcipu lub chęcią jego eksplicytacji w przekładzie. Ważne jest również odróżnienie humoru powstałego w wyniku gry językowej (np. kalambur czy limeryk) od humorystycznych sytuacji, które wyłaniają się stopniowo lub pojawiają się nagle w narracji bądź w fabule utworu. W drugim przypadku nie powinny one stanowić szczególnego problemu tłumaczeniowego, choć podejmując się przekładu, należy pamiętać, że ich znaczenie może zależeć od szerszego kontekstu.

Wybór strategii tłumaczeniowych i powodzenie danego typu humoru zależy od natury obiektu będącego przedmiotem humoru (ludzi, instytucji, poglądów, zachowań), które mogą być rozmaicie postrzegane przez różne społeczności. Tłumacz powinien też być świadom, że niektóre gatunki bardziej niż inne wymagają zastosowania humoru (np. publiczne przemówienia w krajach anglosaskich). W związku z tym autor przekładu musi oszacować, do jakiego stopnia obecność humoru odpowiada wymaganiom gatunku i jakie skutki może wywołać jego obecność lub brak w przekładzie. Musi też oszacować ryzyko związane z przekładem uwarunkowanego kulturowo tabu, zarówno w przypadku dowcipów dotyczących aspektów będących społecznym tabu (polityka, seks, religia), jak również gdy

46 Jak widać, dwie wymienione kategorie nie do końca pokrywają się z wyróżnionymi wcześniej dowcipami ogólnymi, językowymi i kulturowymi. Kategoria dowcipów „ograniczonych” obejmuje zarówno elementy językowe, jak i kulturowe, a barierą w ich przekładzie nie jest nienakładanie się dwóch kultur czy języków, lecz brak wystarczającej wiedzy odbiorcy do ich zrozumienia (o czym świadczy fakt, że istnieją odbiorcy perfekcyjnie znający obce języki i kultury). 
zakazaną praktyką jest sam humor. Zabalbeascoa podkreśla też, że ważniejsza od formy humoru jest jego funkcja (fatyczna, edukacyjna, mnemoniczna i in.).

Jak zauważa badacz, wyzwaniem dla tłumacza może być połączenie humoru werbalnego i niewerbalnego. W tym przypadku konieczna jest często kompensacja elementów humorystycznych związanych z daną kulturą, wyrażonych w oryginale za pomocą kanałów niewerbalnych. Ich utrata mogłaby spowodować poważne luki znaczeniowe w komunikacie. Przeniesienie akcji w inne realia często wymaga zmiany formy humoru (ironia, parodia, karykatura). Tłumacz musi ocenić, w jakim stopniu dana forma wiąże się z intencjami nadawcy oraz jakie są jej funkcje w oryginale ${ }^{47}$.

Zasadniczą rolę w procesie thumaczenia humoru odgrywa ocena skali ważności poszczególnych elementów, mająca wpływ na wybór poszczególnych rozwiązań translatorskich. Zadaniem tłumacza jest sporządzenie listy priorytetów danego thumaczenia i umieszczenie ich na pionowej skali, od najbardziej do najmniej znaczących. Dzięki temu możliwe będzie znalezienie rozwiązań spełniających w pierwszej kolejności priorytety wyższego rzędu, a dopiero po ich zrealizowaniu — niższego. Skala priorytetów związana z rolą humoru (taka sama lub różna w tekście wyjściowym i docelowym) może wyglądać następująco:

- wysoki: komedia filmowa, dowcipy;

- średni: happy end w opowiadaniach romantycznych i przygodowych, quiz telewizyjny;

- marginalny: jako narzędzie pedagogiczne w szkole, humor w tragediach Shakespeare'a;

- niedozwolony: niektóre momenty dramatyczne, np. w tragedii lub w horrorze.

Analiza priorytetów (na poziomie globalnym lub lokalnym tekstu) niekiedy musi być rozszerzona o zbadanie możliwych funkcji humoru (np. krytyka społeczna, narzędzie pedagogiczne, intencja moralizatorska) oraz stanów mentalnych i postaw wyrażonych za jego pomocą (np. postawa ironiczna, cyniczna, prowokacyjna) ${ }^{48}$.

Inny model tłumaczenia humoru został skonstruowany w oparciu o założenia ogólnej teorii humoru werbalnego. Według Attardo idealne thumaczenie humoru, oparte na ekwiwalencji znaczenia, powinno polegać na pozostawieniu bez zmian w języku docelowym wszystkich występujących w oryginale parametrów ujętych w tej teorii. Tłumaczenie warstwy językowej może zakładać minimalną zmianę znaczenia tekstu, jednak nie powinna mieć ona wpływu na efekt humorystyczny ${ }^{49}$.

${ }^{47}$ P. Zabalbeascoa, „Humor and translation - an interdiscipline”, Humor: International Journal of Humor Research 18(2), 2005, s. 189-196.

48 P. Zabalbeascoa, „Translating Jokes for Dubbed Television Situation Comedies”, The Translator 2(2), s. 243-245; P. Zabalbeascoa, „Humor and translation...”, s. 201-202.

49 Dowolność w tłumaczeniu parametrów niższego rzędu (tj. warstwy językowej czy strategii narracyjnej) nie może mieć miejsca w przypadku kalamburów, w których zastosowany mechanizm 
Thumaczenie mechanizmów logicznych nie powinno sprawiać trudności, jeśli wziąć pod uwagę fakt, że niewerbalne mechanizmy logiczne obejmują abstrakcyjne procesy logiczno-dedukcyjne zasadniczo niezależne od języka, a więc łatwo przetłumaczalne.

Bardziej problematyczny jest natomiast przekład skryptów będących w opozycji względem siebie. Hierarchia parametrów ogólnej teorii humoru werbalnego zakłada, że dwa dowcipy różniące się opozycją skryptów mogą być uznane za dwa różne dowcipy. Zmiana opozycji skryptów w thumaczeniu może zatem nastąpić tylko wtedy, gdy język docelowy nie dysponuje podobną opozycją. W przeciwnym wypadku, nawet gdy zmiana opozycji skryptów nie wpłynie na efekt humorystyczny (a tym samym na efekt perlokucyjny), to z semantycznego punktu widzenia nie może być ona uznana za tłumaczenie ${ }^{50}$.

Biorąc pod uwagę przyjętą przez nas definicję przekładu tekstu humorystycznego, ukutą zgodnie z założeniami teorii skopos, trudno zgodzić się ze stwierdzeniem, iż zmiana opozycji skryptów w przekładzie, nawet jeśli prowadząca do podobnych efektów poznawczych u odbiorcy przekładu, nie może być uznana za thumaczenie. Analiza efektów wymaga jednak powiązania technik thumaczeniowych zastosowanych w przekładzie, odzwierciedlających dążenie tłumacza zarówno do udomowienia, jak i do egzotyzacji tekstu oryginalnego, z funkcjami, które efekt humorystyczny pełni w oryginale. Decyzje tłumaczeniowe powinny też być badane $\mathrm{w}$ relacji z ograniczeniami, jakie narzucają teksty multisemiotyczne (adaptacja elementu werbalnego mogłaby np. prowadzić do sprzeczności $\mathrm{z}$ treścią wizualną).

\subsection{NARZĘDZIA ANALIZY PRZEKŁADU HUMORU}

Jako jedno z narzędzi opisu zastosowanych w przekładzie tekstu humorystycznego strategii i technik tłumaczeniowych może posłużyć model opisujący proces thumaczenia dowcipów ${ }^{51}$. Przedstawiony w postaci drzewa binarnego model thumaczenia jednego z rodzajów tekstów humorystycznych nie jest w zamyśle autora preskryptywnym podręcznikiem dla tłumaczy, ale raczej narzędziem opisu przekładu.

Wykres przedstawia rozwiązania służące rozwiązaniu problemu P (thumaczenia dowcipu). Ze wszystkich możliwych rozwiązań tłumacz może posłużyć się takimi, dzięki którym dowcip w tekście docelowym będzie taki sam jak w oryginale (to od tłumacza zależy, jak zostanie zdefiniowana identyczność dowcipów). Dwie

logiczny definiuje również formę językową (fonologiczną czy morfologiczną) tekstu (S. Attardo, „Translation and Humor: An Approach Based on the General Theory of Verbal Humour (GTVH)”, The Translator 8 (2), 2002, s. 190).

50 Ibidem, s. 173-194.

51 P. Zabalbeascoa, „Humor and translation...”, s. 198-201. 
1a Zbiór możliwych rozwiązań $P$ (dowcip)

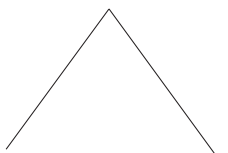

[1] taki sam dowcip Nie

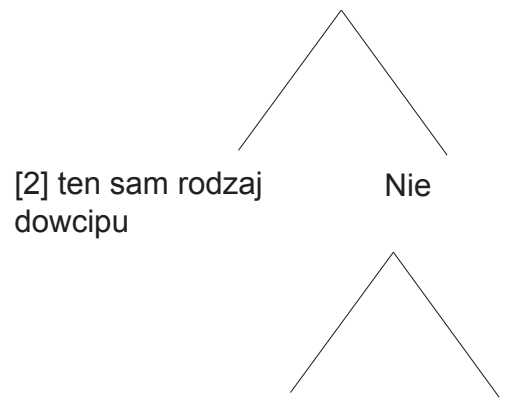

[3] dowcip innego

typu
$1 \mathrm{~b}$ Zbiór możliwych rozwiązań
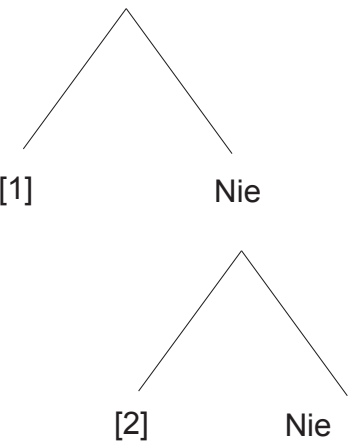

n podziałów binarnych
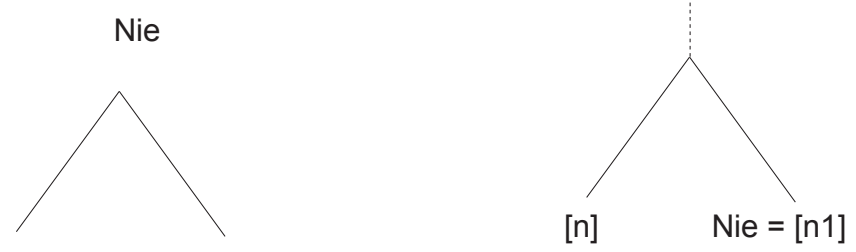

[4] taktyka

[5] brak

kompensacyjna specjalnego efektu

Rycina 1. Model opisu procesu tłumaczenia dowcipów wg P. Zabalbeascoa

inne możliwości polegają na oddaniu dowcipu oryginalnego za pomocą dowcipu tego samego typu, choć zasadniczo nie takiego samego, lub dowcipu innego rodzaju. Kolejne rozwiązanie opiera się na kompensacji utraconego w przekładzie dowcipu za pomocą innych środków, np. hiperboli lub porównania. Ostatnia kategoria obejmuje wszystkie inne możliwości tłumaczenia, jak np. przekazanie dowcipu w bezpośredni, nieretoryczny i niehumorystyczny sposób. Według Zabalbeascoa model binarny może być stosowany w tłumaczeniu tekstów innych niż dowcipy, w których efekt humorystyczny wynika z użycia metafory, ironii czy gry słów, uwzględniając także rozwiązania zastosowane na poziomie werbalnym i niewerbalnym. Na poziomie werbalnym tłumacz może przekładać na język docelowy L2 lub inny język i stosować rozwiązania proste, polegające na przełożeniu elementu języka wyjściowego za pomocą jakiejś jednostki języka docelowego lub ominięcie tego elementu, lub złożone, uzupełniające rozwiązania proste, np. o wstęp, przypis lub komentarz.

Narzędzi analizy przekładu humoru może też dostarczyć obserwacja rzeczywistych rozwiązań translatorskich. Dmitris Asimakoulas przedmiotem badań 
czyni techniki thumaczeniowe zastosowane w greckich thumaczeniach dwóch komedii: Czy leci z nami pilot? (Airplane!, 1980) Johna Abramsa oraz Davida i Jerry'ego Zuckerów i Naga broń (Naked gun, 1988) Davida Zuckera. W obu filmach Asimakoulas wyróżnia pięć głównych nośników humoru: gry językowe, zabawne porównania, aluzje i parodie, elementy humorystyczne wynikające $\mathrm{z}$ ośmieszenia ofiary oraz te mające źródło w użyciu różnych rejestrów językowych. Analiza przekładu dotyczy przede wszystkim elementów humorystycznych wynikających ze specyficznego użycia języka, jak np. kalambury i gry językowe, tylko częściowo uwzględnia natomiast techniki tłumaczeniowe stosowane w przekładzie humoru opartego na interakcji treści na poziomie werbalnym i wizualnym, jak np. parodia.

Jak zauważa autor, poprzez zmianę tropów, generalizację (np. użycie hiperonimów), przeniesienie tylko jednego składnika rozbudowanej metafory czy też pozostawienie w wersji oryginalnej nazwy własnej, niedopasowanej do wiedzy odbiorcy przekładu, tłumacze mogą powodować osłabienie efektu humorystycznego uzyskanego dzięki zabawnym porównaniom i metaforom. Analiza pokazuje też, że trudności może sprawiać przekład odsyłających do tekstów kultury wyjściowej aluzji i parodii, które, zmodyfikowane lub przetłumaczone dosłownie, stają się niejasne dla odbiorcy tłumaczenia. W przypadku humoru będącego przejawem poczucia wyższości zmiana wyśmiewanego obiektu może spowodować dodatkowy efekt humorystyczny (gdy w kulturze docelowej jest on wyjątkowo popularny) lub przeciwnie: pozostawienie tego samego obiektu może spowodować, że przekład stanie się niejasny (w przypadku gdy dany obiekt budzi u odbiorców oryginału i przekładu różne skojarzenia). Spore trudności sprawia też przekład humoru opartego na użyciu socjolektów lub dialektów, dlatego te elementy są najczęściej pomijane w thumaczeniu ${ }^{52}$.

\section{UWAGI KOŃCOWE}

Opisowi humoru w tekstach audiowizualnych i ich przekładach służyć mogą przede wszystkim językoznawcze teorie humoru. Mimo że większość z nich zawęża przedmiot badań do humoru wyrażonego za pomocą języka, a zwłaszcza do jednej z form humoru, jaką są dowcipy, to wydaje się, że niektóre założenia mogą okazać się przydatne również $\mathrm{w}$ analizie humoru, który a) realizuje się w dłuższych formach narracji i wymaga odniesienia do wcześniejszego kontekstu; b) wynika z interakcji treści przekazywanych różnymi kanałami.

Czerpiąc z semantycznej teorii skryptów, z założenia ograniczającej się do językowych form humoru, można scharakteryzować niespójności humorystyczne,

52 D. Asimakoulas, „Towards a Model of Describing Humour Translation. A Case Study of the Greek Subtitled Versions of Airplane! and Naked Gun", Meta : Journal des traducteurs, 49 (4), s. $831-839$. 
wynikające z opozycji między skryptami realizującymi się zarówno na poziomie języka, jak i innych poziomach semiotycznych.

W perspektywie semantyczno-pragmatycznej można następnie określić szczegółowe zjawiska prowadzące do hipotetycznego zaistnienia określonych typów niespójności (językowej, pragmatycznej itp.) bądź wpływające na wzrost poczucia wyższości odbiorcy. Wyrażane w oryginale i przekładzie mechanizmy niespójności można też w ujęciu pragmatycznym rozpatrywać jako rezultat naruszenia przyjętych norm konwersacyjnych, zarówno na poziomie wewnątrz-, jak i zewnątrztekstowym, na poziomie społecznym zaś jako efekt przełamywania rzeczywistych wzorców społecznych.

Porównanie mechanizmów humoru w tekście oryginału jest pierwszym krokiem do przeprowadzenia analizy przekładoznawczej na podstawie przyjętej definicji przekładu tekstu humorystycznego i z uwzględnieniem ograniczeń rządzących danym typem przekładu, np. przekładem audiowizualnym. W eksplicytacji ewentualnych rozbieżności w tekście wyjściowym i docelowym może pomóc typologia zjawisk humorystycznych oparta na kryterium przekładalności. Obserwacja rzeczywistych strategii i technik przekładowych może z kolei zachęcić do poszukiwania uniwersaliów przekładowych - rzeczywistych rozwiązań i potencjalnych trudności, z którymi może spotkać się tłumacz gatunków audiowizualnych. Modele thumaczenia humoru mogą być zastosowane w praktyce przekładowej, mogą też zostać wykorzystane w badaniach nad przebiegiem procesu przekładu humoru audiowizualnego.

\section{HUMOUR IN TRANSLATION STUDIES}

Summary

Humour, manifesting itself at different semiotic levels of a text, is considered to be one of the most common translation challenges. However, previous studies dealing with translation of humour mainly consist of various aspects of translating humorous phenomena expressed themselves especially at the linguistic level. The aim of the article is to present the most important linguistic theories of humor (structural isotopy, semantic theory of scripts, the general theory of verbal humor, humor seen as a violation of the conversational maxims or as the game with implicatures), as well as some observations in the field of translation studies, and subsequently to develop describing tools for the translation of humorous phenomena in audiovisual texts.

Key words: humour, audiovisual translation, linguistic theories of humour. 